\title{
The characterization of Post-Mortem Sperm of Local Chicken Cocks in Eastern Algeria
}

\author{
Houria Ouennes ${ }^{1 *}$, Farida Afri Bouzebda ${ }^{1}$, Zoubir Bouzebda $^{1}$, Sara Majdoub $^{2}$, Amel Djaout $^{3}$ \\ and Moustapha Adnane Smadi ${ }^{2,4}$ \\ ${ }^{1}$ Laboratory of Animal Production, Biotechnology and Health (PABIOS), Institute of Veterinary and Agricultural Sciences, Department of \\ Veterinary Science, University of Mohamed Cherif MessaadiaSouk ahras, Algeria \\ ${ }^{2}$ National Center for Biotechnology Research (CRBt), Ali Mendjli Nouvelle Ville Uv 03 Bp E73 Constantine, Algeria \\ ${ }^{3}$ Algeria's National Institute for Agricultural Research (INRAA), Setif, Algeria \\ ${ }^{4}$ Veterinary and Agricultural Sciences Institute, Department of Veterinary Sciences, University of Batna, Batna, Algeria
}

*Corresponding author's Email: webhouria36@hotmail.fr ; ORCID: $\underline{\text { 0000-0003-3485-0858 }}$

Received: 24Apr. 2019

Accepted: 23May. 2019

\begin{abstract}
The present aimed to investigate for the first time the characteristics and conservation of post-mortem sperm, obtained from epididymis and the vas deferens of 18 pairs of adult local chicken cocks from the east of Algeria (age, $12-24$ months, body weight $1.50-2.53 \mathrm{~kg}$ ). And compare the sperm quality at the epididymis and the vas deferens levels, the efficacy of two post-mortem sperm retrieval techniques, the flushing and float-out methods in the collection of local chicken cock's sperm, and the effects of conservation in situ at different temperatures $(2 \mathrm{~h}$ and $24 \mathrm{~h}$ at $20^{\circ} \mathrm{C}$ and after refrigeration at $4^{\circ} \mathrm{C}$ for $\left.24 \mathrm{~h}\right)$. The quality was significantly higher $(0.13 \pm 0.05 \mathrm{ml}$ vs $0.72 \pm 0.12 \mathrm{ml})$ in the vas deferens compared to the epididymis, whereas spermatozoa abnormalities and chromatin quality did not differ in both the epididymis and vas deferens. No significant difference was observed between the flushing and float-out methods. Concentration ( $3.33 \pm 1.63$ million sperm vs $1.75 \pm 0.76$ million sperm), initial motility $(77.50 \pm 6.89 \%$ vs $75.83 \pm 8.61 \%)$, viability $(75 \pm 10.39 \%$ vs $74.67 \pm 10.15 \%)$ and abnormality $(30.33 \pm 4.68 \%$ vs $30.33 \pm 4.68 \%)$, only the volume was significantly higher $(0.72 \pm 0.12 \mathrm{ml}$ vs $0.17 \pm 0.08 \mathrm{ml})$. However, the effects of conservation in situ, at $25^{\circ} \mathrm{C}$ and $4^{\circ} \mathrm{C}$ for $24 \mathrm{~h}$, showed a significant difference for viability and motility of the spermatozoa recovered from vas deferens, and no significant difference for abnormality and acrosome integrity. Therefore, it can be concluded that good quality semen samples can be collected from the vas deferens with the flushing method, and semen of Algerian local cocks can be preserved at $20^{\circ} \mathrm{C}$ for $24 \mathrm{~h}$.
\end{abstract}

Key words:Conservation, Eastern Algeria, Epididymis, Local cocks, Post-mortem, Vas deferens

\section{INTRODUCTION}

Actually, a plethora of research focused on the conservation of genetic resources and biodiversity (Blesbois, 2007). The importance of granting poultry genetic resources from unexpected accidents or disease outbreaks cannot be overemphasized (Sasaki et al., 2010). Local poultry breeds may cause an interesting different option to commercial lines, supplying high-quality products of great interest for local and regional markets (De Marchi et al., 2005). Poultry products, meat and eggs, obtained from native breeds show specific features (De Marchi et al., 2005; Castellini et al., 2006; Zanetti et al., 2011) which distinguish them from standard ones, moreover, breeds can be reared in outdoor free-range systems and even used to reintroduce agricultural activity in marginal rural areas. Traditionally, the creation of banks of semen doses from endangered breeds is performed using the protocols developed for commercial breeds or lines (Blesbois, 2007).

In addition to experimental lines and commercial stocks contributing to the range of chicken genetic diversity, traditional chicken breeds are still highly connected to cultural values, geographical origins and adapted to local environments; however, many of them have undergone a major decrease in their population size, thus increasing erosion of their genetic diversity (Woelders et al., 2006). The loss of valuable genes and rapid decrease in biodiversity as a result of a smaller number of selected breeds used for breeding has resulted in an urgent need to create gene banks and databanks 
(Tisdell, 2003). In poultry species, semen cryopreservation is currently the most practical method for long-term storage of genetic material (Blesbois, 2007).

The most frequent method of semen collection in birds is Dorso-abdominal massage (Chelmonska et al., 2008). But it has been proven that this method of harvesting is harmful to sperm due to sperm contamination during urinary retrieval (Blanco et al., 2002). The use of the post-mortem harvest of spermatozoa by the various methods (like Swim-up and mincing), was a way of overcoming the inconveniences of the abdominal massage, which has already been found in Philippine roosters (Salting et al., 2016). Germplasm banks for endangered avian species are still being set up. Gunn et al. (2008) described and compared different techniques for postmortem sperm collection in wild pukekos (Porphyrio porphyrio melanotus), although none of the cells obtained was motile. Some authors, because they did not evaluate the viability of the sperm nor the effectiveness of its extension suggested that the pukeko sperm is not mobile in the vas deferens and becoming active only after ejaculation, or that those recovered are simply dead (Gunn et al., 2008).

Sadly, the avian spermatology is not simple, which is necessary to improve sperm cryopreservation (VillaverdeMorcillo, 2016). However, sperm may also be useful to create germplasm banks of sperm from dead birds by feeding information on the physiological status of the donor used for reproduction (Kumar and Holt, 2014). Semen evaluation prior to its further processing is essential and an important prerequisite. In order to propose the devising methods for the storage of fowl spermatozoa, it is necessary to evaluate the basic quality of sperm (Lukaszewicz et al., 2008). To ensure the better cryopreservation, it is essential to appreciate the mobility, morphology and the metabolism of fresh semen (Blesbois, 2007). This study was conducted to characterize postmortem sperm of local Algeriancocks collected from the epididymis and the vas deferens, find the suitable methods of extract the sperm and the effects of conservation in situ at different temperatures ( 2 hours and 24 hours at $20^{\circ} \mathrm{C}$ and after refrigeration at $4^{\circ} \mathrm{C}$ for $24 \mathrm{~h}$ ).

\section{MATERIALS AND METHODS}

\section{Ethical approval}

The experiment was carried out according to the national regulations on animal welfare and institutional animal ethical committee of national center for biotechnology research, Constantine, Algeria.

\section{Semen collection and evaluation}

The birds used in present investigation were local cocks from the east of Algeria (El Tarf and Constantine). $12-24$ months of age and $1.50-2.53 \mathrm{~kg}$ live body weight were used in this experiment. Procedures were performed using sperm obtained post-mortem from the epididymis and the vas deferens of 18 pairs adult cockshumanely euthanized by cervical dislocation. Testes with their corresponding vas deferens were collected within one hour after slaughtering by opening the carcass along the midline. All the viscera were removed and the testes extracted together with the ureter and renal vasculature, thus damages to the vas deferens was avoided. The ureter and renal vasculature were carefully dissected out to minimize blood and urine contamination of the sperm sample (Figure 1). Once the epididymis and vas deferens were isolated from the testes and adjacent tissues, sperm collection was performed either by the flushing or floatout method from the vas deferens (one testis via the flushing method, and the other by the float-out method), and the epididymis employed simply by the mincing method. Following sperm collection, sperm variables were assessed before refrigeration and 24 hours at environment temperature, then after cooling in situ at $4^{\circ} \mathrm{C}$ for 24 hours.

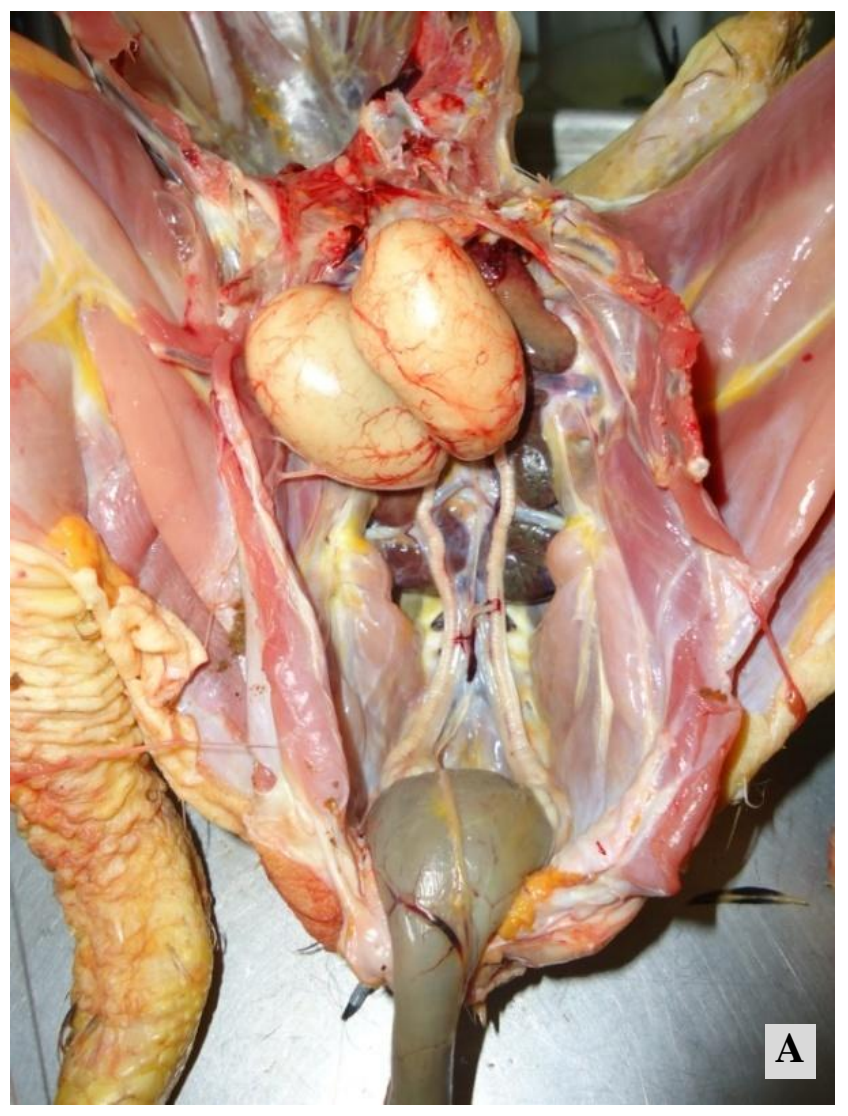




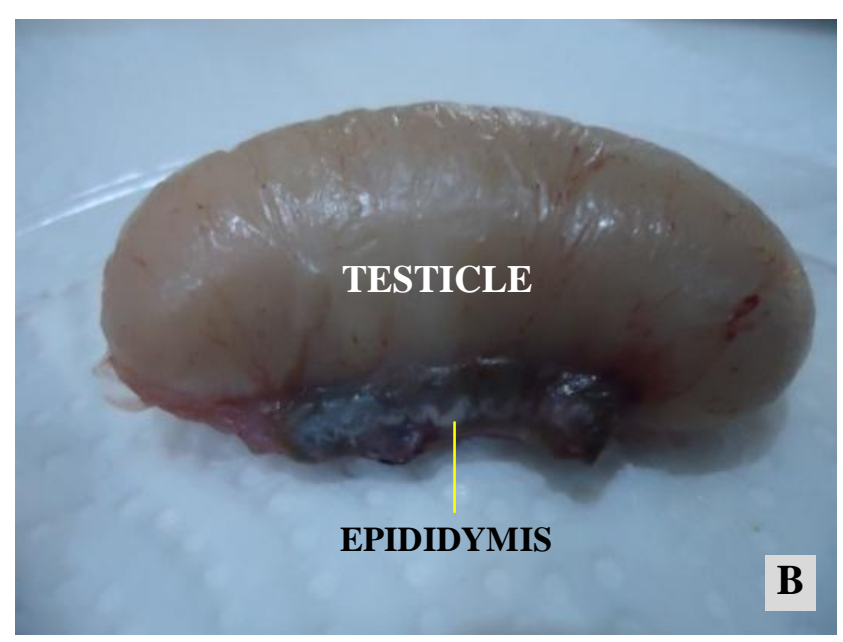

Figure 1.Anatomy of reproductive tract of adult local cocks' in Eastern Algeria(A and B)

\section{Mincing method}

The Mincing technique involves isolating the epididymis from the testis, placed in microcentrifuge tubes containing 400 $\mu 1$ of Phosphate Buffered Saline (PBS) and were minced by using sterile surgical scissors, and then left to stand for 10-15 minutes. The upper liquid portion was transferred to another microcentrifuge tube (Salting et al., 2016).

\section{Flushing method}

Samples were obtained by injecting $1.5 \mathrm{ml}$ of saline solution at $38^{\circ} \mathrm{C}$ into the proximal extreme of the vas deferens using a $27 \mathrm{G}$ needle attached to a $5 \mathrm{ml}$ syringe (Figure 2). The entire volume of the saline solution and the collected sperm were placed in a sterile plastic Petri, from which they were transferred to a polystyrene tube $(2 \mathrm{ml})$. The samples were then incubated at $38^{\circ} \mathrm{C}$ for $15 \mathrm{~min}$ (Villaverde-Morcillo, 2016).

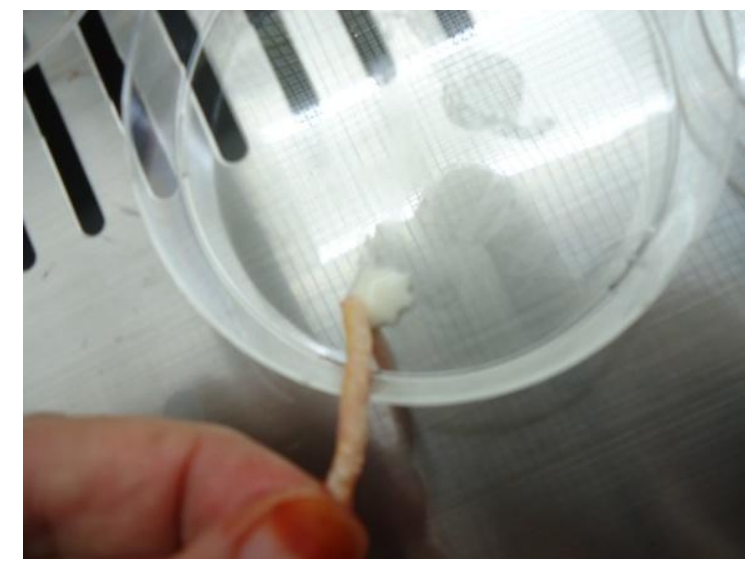

Figure 2. Extraction the sperm from Vas deferens 2hours after slaughtering of local cocks' in Eastern Algeria by flushing method

\section{Float-out method}

The vas deferens was cut into $0.5 \mathrm{~cm}$-long pieces which were submerged in $1.5 \mathrm{ml}$ of saline solution at $38^{\circ} \mathrm{C}$ in a $2 \mathrm{ml}$ tube. These samples were then incubated at $38^{\circ} \mathrm{C}$ for $15 \mathrm{~min}$ (Villaverde-Morcillo, 2016).

\section{Sperm assessment}

Semen volume $(\mathrm{ml})$ was measured visually using a graduated collection tube. The total volume retrieved after flushing or float-out was considered as the final sperm volume to calculate sperm concentration. The concentration of spermatozoa (million per millilitre) was determined by using a calibrated spectrophotometer. The wavelength is set at $650 \mathrm{~nm}$. The addition of $3 \mathrm{ml}$ of a $2.9 \%$ sodium citrate solution (PH 7.0). A drop of semen $(10 \mu \mathrm{l})$ was placed on a clean, pre-warmed $\left(41^{\circ} \mathrm{C}\right)$ microscope slide using a micropipette. A clean cover slip was placed gently to avoid air bubble formation. Sperm motility was demonstrated by the progressive wavy movement of sperm cells. Briefly, $20 \mu 1$ aliquot from sperm suspension was stained by $20 \mu \mathrm{l}$ Eosin-Nigrosine dye. Then, smears were prepared on a warm slide and the stain spread with a second slide. Twenty hundred sperm were counted under phase-contrast at 1000x magnification. Acrosomal integrity was studied using Giemsa staining (Watson, 1975).

\section{Acidic aniline blue staining}

Sperm chromatin condensation was disturbed (NCI) when lysine-rich somatic histones were not sufficiently substituted by arginine-rich protamines during spermiogenesis. Histone-containing spermatozoa can be visualized using acidic aniline blue staining solution, which reacts with lysine residues of persisting histones (Shanmugam et al., 2016). The percentage of sperm heads partially or entirely stained dark blue was examined according to the procedures described by Boitrelle (2004).

\section{Statistical analysis}

Data were analyzed using SPSS software (version 19). The effect of the level of epididymis or the vas deferens, two sampling techniques (Float-out and flushing methods), and the time of conservation of the gonads ( $2 \mathrm{~h}$, $24 \mathrm{~h}$ at $25^{\circ} \mathrm{C}$ and $24 \mathrm{~h}$ at $4^{\circ} \mathrm{C}$ ) on the sperm quality were compared by the one-way ANOVA test followed by the Student Newman-Keuls multiple comparison test. Mean values were considered significantly $(\mathrm{P}<0.05)$, data are expressed as values \pm Standard Deviation (SD). 


\section{RESULTS AND DISCUSSION}

Various parameters of spermatozoa collected from the epididymis and the vas deferens

Mean values of volume, initial motility, concentration, viability, abnormality and aniline blue negative spermatozoa (chromatin quality) were presented in table 1. The volume, concentration, motility and viability of spermatozoa were significantly $(\mathrm{P}<0.05)$ influenced by the level of sampling. They were significantly higher $(\mathrm{P}<0.001)$ in the vas deferens compared to the epididymis. While spermatozoa abnormalities and chromatin quality do not differ in the epididymis and the vas deferens $(\mathrm{P}>0.5)$.

Table 1. Comparison of sperm quality at the level of the epididymis and the vas deferens from local cocksin Eastern Algeria

\begin{tabular}{lccc}
\cline { 1 - 3 } Items & Epididymis & Vas deferens & \multirow{2}{P}{} \\
\cline { 1 - 3 } $\mathbf{N}$ & $\mathbf{1 2}$ & $\mathbf{1 2}$ & $* * *$ \\
\cline { 1 - 3 } Volume (ml) & $0,13 \pm 0,05$ & $0,72 \pm 0,12$ & $* * *$ \\
\hline Concentration $\left(10^{6}\right)$ & $250 \pm 137,84$ & $5333,33 \pm 1861,90$ & $* * *$ \\
\hline Initial motility $(\%)$ & $65,83 \pm 4,92$ & $80,83 \pm 7,36$ & $* *$ \\
\hline Viability (\%) & $53,17 \pm 9,13$ & $86,50 \pm 2,59$ & $* * *$ \\
\hline Abnormality (\%) & $21,17 \pm 3,37$ & $20,67 \pm 13,43$ & $\mathrm{~ns}$ \\
\hline $\begin{array}{l}\text { Aniline blue } \\
\text { negative (\%) }\end{array}$ & $78,17 \pm 4,75$ & $76,17 \pm 6,62$ & $\mathrm{~ns}$ \\
\hline Nombre (n), no significant difference (ns)** $\mathrm{P}<0.01$ and $* * * \mathrm{P}<0.001$
\end{tabular}

The results confirmed the findings of Munro (1935 and 1938), which reported that sperm motility increased somewhat in the rudimentary epididymis of birds, but the maximum motility was seen in the vas deferens. Avian spermatozoa are not motile in the testes, although they have been found to be capable of fertilizing eggs when taken from the testes. Because spermatozoa are mature at this stage (Jones and Lin,1993). The role of epididymal region of the rooster reproductive tract is the production of fertile sperm. But testicular effluent is concentrated and surface of sperm cells altered by passing through the excurrent ducts of the epididymis (Clulow and Jones, 1988). These changes presumably revealed base on differences in the function of sperm recovered from the testis and deferent duct (Howarth, 1983). Clulow et al. (1988) reported that before the sperm stored for an extended period in the ductus deferens, these ducts resorb nearly $90 \%$ of the testicular plasma outputwhen the sperm traverse this region of the male reproductive tract rapidly. The assessment of the basic quality of sperm is indispensable for the purpose of devising methods for the storage of fowl spermatozoa in vitro for long periods of time (Łukaszewicz et al., 2008). Salting et al. (2016) expressed for choosing semen at good quality level, colour must be free of any contamination caused by cloacal products, the volume greater than $0.3 \mathrm{ml}$, sperm mobility greater than $65 \%$, and sperm concentration greater than $1 \times 10^{9}$ sperm cells $/ \mathrm{ml}$. This study addressed the contribution of the epididymis to the attainment of functional maturity of local cocks' spermatozoa. In contrast to their mammalian counterparts, where it is well established that spermatozoa undergo a number of important changes in the epididymis, present study obtained few changes in the functional profile of indigenous cocks spermatozoa at epididymis. These results are in accordance with the fundamental differences in the anatomy and biology of the avian and mammalian reproductive systems (Jones et al., 2003). Accordingly, the vas deferens (leading from the testes to the cloaca) should be the ideal site to harvest mature sperm (Gunn et al., 2008). The results of the study proved that good quality semen samples can be collected from the vas deferens of local cocks with parameters comparable to ejaculated sperm of some strains. Samples collected from the vas deferens can be considered as a better source for future rooster semen studies regarding the development of methods of chicken sperm cryopreservation and, eventually, in cryopreservation per of valuable genetic resources. Because, the basis of sperm can be a suitable indicator in AI practices (Mavi et al., 2017).

\section{Spermatozoa retrieved of the vas deferens by float-out and flushing methods}

This study was the first comparing two post-mortem sperm retrieval techniques of cocks' sperm from the vas deferens of Algerian local cocks, retrieved by flushing and float-out methods. Table 2 presents the comparison of motility, viability, concentration and percent abnormality observed in the samples retrieved using flushing method and float-out method. It indicates that the volume of sperm (ml) retrieved by flushing was $0.72 \pm 0.12$, but with the float-out method, it was $0.17 \pm 0.08$. The difference was significantly higher $(\mathrm{P}<0.01)$, the volume harvested by float-out method was lower than Aseel $(0.36 \pm 0.08)$ and Kadaknath $(0.30 \pm 0.06 \mathrm{ml})$ breed (Mavi et al., 2017), and of Venda cockerels (0.3ml) (Mphaphathi et al., 2016), obtained by abdominal massage technique.

The concentrations of sperm (billion cells per millilitre) retrieved by flushing and float-out methods found were $3.33 \pm 1.63$ and $1.75 \pm 0.76$, respectively. The ttest did not obtain significant $(\mathrm{P}>0.05)$ differences between the concentrations of samples retrieved using 
flushing and float-out methods. In the present study, the methods of collecting caused low concentration than harvested by abdominal massage technique $\left(6.8 \times 10^{9} / \mathrm{ml}\right)$ from Venda chicken (Mphaphathi et al., 2016). Siudzinska and Lukaszewicz (2008) reported an average sperm concentration of $4.7 \times 10^{9} / \mathrm{ml}$ in White Crested Black Polish cocks and $4.2 \times 10^{9} / \mathrm{ml}$ in the Black Minorcas breeds. Tuncer et al. (2008) and Obidi et al. (2008) reported sperm concentrations at levels of $2.4 \times 10 \% / \mathrm{ml}$ in Gerze cocks and $3.6 \times 10^{9} / \mathrm{ml}$ in Shikabrown cocks similar to present findings.

The study of Villaverde-Morcillo et al. (2016) demonstrated the interaction between recovery methods and sperm diluents did not exert significant influence on sperm variables. Irrespective of the extender used, significantly more sperm was retrieved by the flushing method than by the float-out method (5965754 million sperm per vas deferens 3410876 million sperm per vas deferens, $\mathrm{P}<0.05$ ), indeed, the number was similar to that recorded for the ejaculated sperm (6303782 million sperm). The float-out was among the easiest techniques to perform, and although a low amount of sperm was obtained, there was a much lower incidence of extraneous cells in the sample, making it easier to find sperm. This technique was also the least likely to damage sperm and has the greatest likelihood for obtaining mature sperm, as only those sperm that was free in the lumen was included in the solution (Gunn et al., 2008). According to Salting et al. (2016), the concentrations of samples retrieved from the excurrent ducts, regardless of the retrieval method used, were found at the normal range in ejaculated samples.

Table 2. Comparison of two post-mortem sperm retrieval techniques of local cocks' in Eastern Algeria

\begin{tabular}{lccc}
\hline Items & $\begin{array}{c}\text { Float-out } \\
\text { method }\end{array}$ & $\begin{array}{c}\text { Flushing } \\
\text { method }\end{array}$ & $\begin{array}{c}\text { P } \\
\text { value }\end{array}$ \\
\cline { 1 - 3 } $\mathbf{N}$ & $\mathbf{6}$ & $\mathbf{6}$ & \\
\hline Volume $(\mathrm{ml})$ & $0.17 \pm 0.08$ & $0.72 \pm 0.12$ & $* * *$ \\
\hline Concentration $\left(10^{6}\right)$ & $1.75 \pm 0.76$ & $3.33 \pm 1.63$ & $\mathrm{~ns}$ \\
\hline Initial motility $(\%)$ & $75,83 \pm 8.61$ & $77.50 \pm 6.89$ & $\mathrm{~ns}$ \\
\hline Viability $(\%)$ & $74.67 \pm 10.15$ & $75.00 \pm 10.39$ & $\mathrm{~ns}$ \\
\hline Abnormality $(\%)$ & $30.33 \pm 4.68$ & $30.33 \pm 4.68$ & $\mathrm{~ns}$ \\
\hline Number $(\mathrm{n}),{ }^{*} * * \mathrm{p}<0.001$ and no significant difference $(\mathrm{ns})$ &
\end{tabular}

Results impliedthat concentrations of spermatozoa obtained from the excurrent ducts were comparable with the concentrations of spermatozoa in samples obtained via dorso-abdominal massage method. The normal concentration of spermatozoa varies between individuals of the same species (Glover, 2012), it has been estimated between 1.7 and 3.5 billion spermatozoa per millilitre of chicken (Hicks, 1992), these numbers are consistent with the results found in this study.

As shown on the table 2, the motility of samples retrieved using the float-out was $75.83 \pm 8.61 \%$ and $77.50 \pm 6.89 \%$ for flushing method. T-test revealedno significant difference $(\mathrm{P}>0.05)$ between the motility of the float-out and the flushing retrieved spermatozoa indicating that the retrieval method did not significantly affect or improved the resulting percentage of motile and progressive spermatozoa in the sample collected. Which was higher $(65.5 \pm 4.97 \%)$ than findings obtained by Salting et al. (2016) (swim-up method) and $65 \pm 4.71 \%$ (mincing method). Higher sperm motility has been observed in freshly ejaculated semen of cocks $(66.67 \pm 6.67 \%$ to $86.5 \pm 0.78 \%)$ as reported in earlier studies (Almahdi and Ondho, 2014; Churchil et al., 2014). The flushing method affected more negatively than float out method on a percentage of sperm showing progressive motility (Villaverde-Morcillo et al., 2016). The float-out method, which has been used with the pukeko (Gunn et al., 2008) and mice (Mohammadzadeh et al., 2011), that was easier to perform and faster than the flushing method, but the sperm samples were usually contaminated with blood cells and urates, adversely affecting the long-term storage of the sperm, because the presence of white blood cells may increase the production of reactive oxygen species, according to Aitken and Bennetts (2006). Unlike the flushing method reduced contamination by blood cells and urates, according to Villaverde-Morcillo et al., (2016), and have shown that the flushing method was more effective. However, recovering roughly the same number of sperm is in a single vas deferens as in ejaculates.

Percentage of live spermatozoa in the sample retrieved by the float-out was found at $74.67 \pm 10.15 \%$ whereas, for flushing methods retrieved spermatozoa, viability was $75.00 \pm 10.39 \%$. Statistical analysis shows no significant $(\mathrm{P}>0.05)$ difference between the viability of the float-out and flushing methods retrieved spermatozoa (Figure 3). Results indicated that the retrieval method had no effect on the resulting percentage of viable sperm in the sample. The viability of samples obtained in this study was lower than that obtained of the excurrent ducts by Salting et al. (2016), $85.65 \pm 7.88 \%$ (float-out method) and $84.20 \pm 8.79 \%$ (mincing method), and to the results of these earlier studies (Tabatabaei et al., 2009; Tarif et al., 2013; Churchil et al., 2014). The percentage of live spermatozoa in the excretory ducts would be similar to that of ejaculated samples in domestic poultry because the spermatozoa mature and become fully fertile in the vas 
deferens. It was also in the vas deferens where sperm produced by the testicles were stored until the rooster's companion (Salting et al., 2016). These differences may be explained by breed, location, nutrition, age and climate differences because the sperm parameters can vary depending on these factors (Das et al., 2016; Kuzlu and Taskin, 2017; Mavi et al., 2018).

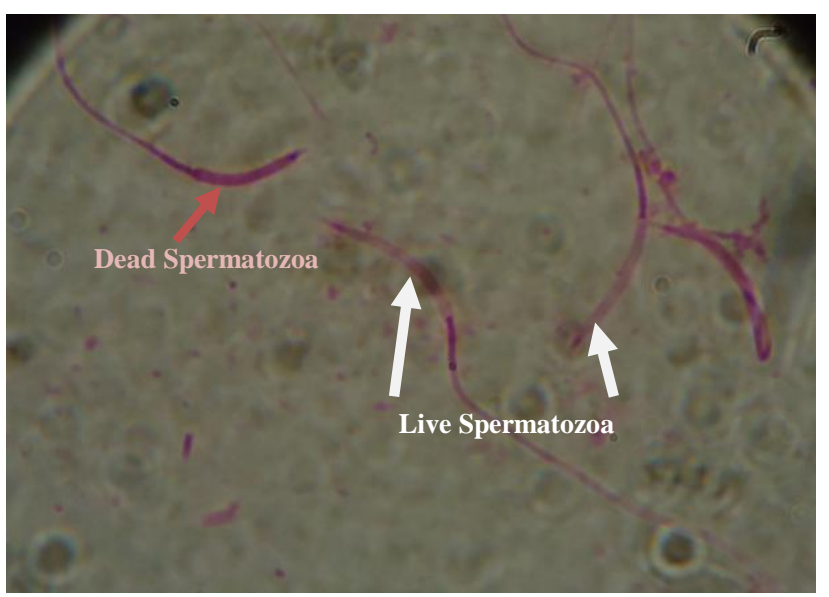

Figure 3. Assessment of sperm viability at local cocks' in Eastern Algeriawith eosin nigrosin (white: live spermatozoa, pink: dead spermatozoa)

As presented in table 2, the percentage of morphologically abnormal spermatozoa in samples retrieved by float-out was $30.33 \pm 4.68 \%$ while $30.33 \pm 4.68$ $\%$ abnormality was observed in flushing retrieved samples too. No difference was found between the percentages of abnormality of spermatozoa retrieved using float-out and flushing method. The percentages of abnormal spermatozoa observed in this study from vas deferens collected by both techniques (float-out and flushing method) were higher than those observed from ejaculated spermatozoa of various strains in studies conducted by Tarif et al. (2013) and Churchil et al. (2014), which ranged from $4.52 \pm 10 \%$ to $23.33 \pm 6.67 \%$ and lower than reported by Tabatabaei et al. (2009) in exotic Ross-308 and indigenous chicken in Iran ranged from $41.04 \pm 10.19 \%$ to $44.1 \pm 0.26 \%$, respectively. Although this may be attributed to the genetic or intrinsic factors of Algerian local cocks, unfortunately, pieces of literature regarding the characterization of semen ejaculates of local breeds or strains were lacking. In this study, the isolation of spermatozoa from vas deferens of Algerian indigenous cocks was made possible and the difference between the quality of spermatozoa retrieved by float-out and flushing method was also studied. The flushing method allows for obtaining higher numbers of sperm. This technique can be easily performed on wild and domestic birds found dead or critically injured, which can be interesting in breeding and conservation programs. Many studies have shown that different factors include species, age, weight and others play significant roles in the differences in semen parameters (Salting et al., 2016)

A similar study of the harvest and storage specific to the specific strain for Algerian local chickens was recommended. In addition, other in vitro tests and subsequent correlation with cryo survivability have been suggested.

The effects of conservation the vas deferens at different temperatures

The effect of temperature on sperm quality during storage in situ, $2 \mathrm{~h}$ after slaughter $\left(20^{\circ} \mathrm{C}\right), 24 \mathrm{~h}$ at $20^{\circ} \mathrm{C}$ and $24 \mathrm{~h}$ at $4^{\circ} \mathrm{C}$ is shown in table 3 . In this study, the quality of sperm samples obtained from vas deferens of local cocks, stored $24 \mathrm{~h}$ at $4^{\circ} \mathrm{C}$ and at $20^{\circ} \mathrm{C}$, after slaughtering was also determined. Holding spermatozoa at temperatures below body temperature prior cryopreservation was commonly done in many species with acceptable results. Since refrigeration devices were widely available, testes of animals could be kept at $4^{\circ} \mathrm{C}$ during its storage.

Table 3. Effects of conservation the vas deferens at different temperatures of localcocks' in Eastern Algeria

\begin{tabular}{|c|c|c|c|c|}
\hline & $2 \mathrm{~h}$ & $24 \mathrm{~h} 4^{\circ} \mathrm{C}$ & $24 \mathrm{~h} 20^{\circ} \mathrm{C}$ & $\mathbf{P}$ \\
\hline $\mathbf{N}$ & 6 & 3 & 3 & value \\
\hline $\begin{array}{l}\text { Initial } \\
\text { motility }(\%)\end{array}$ & $81,00 \pm 2,19$ & $55,00 \pm 5,00$ & $83,00 \pm 7,21$ & $* * *$ \\
\hline Viability (\%) & $75,50 \pm 11,11$ & $48,33 \pm 3,51$ & $81,00 \pm 7,21$ & $* *$ \\
\hline $\begin{array}{l}\text { Abnormality } \\
(\%)\end{array}$ & $32,00 \pm 4,65$ & $32,00 \pm 4,36$ & $29,67 \pm 2,52$ & $\mathrm{~ns}$ \\
\hline $\begin{array}{l}\text { Acrosome } \\
\text { integrity (\%) }\end{array}$ & $75,67 \pm 10,61$ & $75,33 \pm 2,52$ & $81,67 \pm 7,51$ & ns \\
\hline
\end{tabular}

In the present study, the motility of spermatozoa collected from the vas deferens, and conserved at $24 \mathrm{~h}$ in $4^{\circ} \mathrm{C}(55 \pm 5 \%)$, while, at $20^{\circ} \mathrm{C}(83 \pm 7.21 \%)$, were significantly higher $(\mathrm{P}<0.01)$, in comparison to that of control spermatozoa from non-refrigerated vas deferens (immediatelyafter slaughtering) $(81 \pm 2.19 \%)$ and after conservation at $4^{\circ} \mathrm{C}$. Unlike in present study, the motility decreases significantly $(\mathrm{P}<0.01)$ during in-vitro storage and after $24 \mathrm{~h}$ at $20^{\circ} \mathrm{C}$, was seen $30.6 \%$. Semen samples stored at $5^{\circ} \mathrm{C}$ revealed an overall motility more than $50 \%$ after $24 \mathrm{~h}$ (Mphaphathi et al., 2016), semen samples of the Venda breed record the motility of $55 \%$ after $24 \mathrm{~h}$ in vitrostorage at $5^{\circ} \mathrm{C}$ while, semen samples stored at $25^{\circ} \mathrm{C}$, caused a drastic reduction to $30 \%$ after $24 \mathrm{~h}$ (Mphaphathi 
et al., 2016). According to Clarke et al. (1982), cock semen stored at $41^{\circ} \mathrm{C}$ drastically decreased the sperm motility compared to that stored at 5,15 and $25{ }^{\circ} \mathrm{C}$. There were also significant differences concerning, the viability of the spermatozoa recovered from vas deferens stored at $4^{\circ} \mathrm{C}$ and at $20^{\circ} \mathrm{C}(48.33 \pm 3.51 \%$ and $81 \pm 7.21 \%)$. In contrast, abnormal spermatozoa $(32 \pm 4.36 \%$, $29.67 \pm 2.52 \%)$ and acrosome integrity $(75.33 \pm 2.52 \%$, $81.67 \pm 7.51 \%$ ) did not obtain significant differences.

\section{CONCLUSION}

It was concluded that good quality of spermatozoa could be collected from vas deferens, and it is possible to preserve semen of Algerian local cocks at $4^{\circ} \mathrm{C}$ and $20^{\circ} \mathrm{C}$ for 24 hours. It is obtained that high quality semen from vas deferens of local cocks can be purposed for a further study on cryopreservation in order to create a gene bank of the local Algerian chicken cocks

\section{DECLARATIONS}

\section{Acknowledgments}

The authors are thankful to Mr Seidira Chamssedine, from biotechnology animal lab (national center for biotechnology research -CRBt), for sample collection.

\section{Author's contribution}

Bouzebda Afri Farida and Bouzebda Zoubir were mainly responsible for the tabulation of experimental data and article writing under the supervision of Majdoub Sara, Djaout Amel and Smadi Moustapha Adnane.

\section{Consent to publish}

All authors gave their informed consent prior to their inclusion in the study.

\section{Competing interests}

The authors declare that they have no conflict of interest with respect to the research, authorship, and/or publications of this article.

\section{REFERENCES}

Akhlaghi A, Ahangari YJ and Zhandi M and Peebles E ( 2014). Reproductive performance, semen quality, and fatty acid profile of spermatozoa in senescent broiler breeder roosters as enhanced by the long-term feeding of dried apple pomace. Animal Reproduction Science, 147: 64-73. DOI:https://doi.org/10.1016/j.anireprosci.2014.03.006.

Almahdi AB and Ondho YS (2014). Comparative studies of semen quality on different breeds of chicken in Poultry Breeding Center, Temanggung-Central Java. International Refereed Journal of Engineering and Science, 3(2): 94$103 . \quad$ DOI:http://www.irjes.com/Papers/vol3issue2/K030294103.
Beltran MAG (2011). Cryopreservation of goat semen for A.I. Knowledge Resource Management Center, Philippine Carabao Center, pp 44.

Blesbois E (2007). Current status in avian semencryopreservation. World's Poultry ScienceJournal, 63 : 213-222. DOI:https://doi.org/10.1017/S0043933907001419.

Blanco JM, Gee GF, Wildt DE and Donoghue AM (2002). Producing progeny from endangered birds of prey:Treatment of urine-contaminated semen and a novel intra-magnal insemination approach. Journal of Zoo and $\begin{array}{lll}\text { Wildlife } \quad \text { Medicine, } & \text { 33(1): }\end{array}$ DOI:https://doi:10.1638/1042-7260

Boitrelle F (2014). Liens entre la morphologie et les marques epigenetiques, la qualite de l'ADN, le contenu chromosomique et les capacites fecondantes du spermatozorde humain. Medecine humaine et pathologie. Universite de Versailles-Saint Quentin en Yvelines, Français, p. 66.

Budras KD and Sauer T (1975). Morphology of the epididymis of the cock Gallus domesticus and its effect upon the steroid sex hormone synthesis. I. Ontogenesis morphology and distribution of the epididymis. Anatomy and Embryology, 148: 175-196. DOI:https://doi.org/10.1007/BF00315268.

Chelmonska B, Jerysz A, Lukaszewicz E, Kowalczyk A and Malecki I (2008). Semen collection from Japanese quail (Coturnix japonica) using a teaser female. Turkish Journal of Veterinary and Animal Sciences, 32(1) :19-24.

Castellini C, Dal Bosco A, Mugnai C and Pedrazzoli M (2006). Comparison of two chicken genotypes organically reared: oxidative stability and other qualitative traits. Italian Journal of Animal Science, 5(1): 29-42. DOI:https://doi.org/10.4081/ijas.2006.29.

Churchil RR, Praveena PE and Sharma D (2014). Semen quality parameters, their inter-relationship and post-washing sperm attributes of Rhode Island Red rooster. Veterinary World, 7(12): 1117-1122. DOI:https://doi.org/10.14202/vetworld.2014.1117-1122.

Clarke RN, Sexton TJ and Ottinger MA (1982). Effet of holding temperature and storage time on resperatory rate, motility and fertility of chicken and turky semen. Poultry Science, 61: 1912-1917. DOI:https://doi.org/10.3382/ps.0611912.

Clulow J and Jones RC (1988). Studies of fluid and spermatozoal transport in the extratesticular genital ducts of the Japanese quail. Journal of Anatomy, 157:1-11. Available at:https://www.ncbi.nlm.nih.gov/pubmed/3198469

Clulow J and Jones RC (1982). Production, transport, storage and survival of spermatozoa in the male Japanese quail, Coturnix coturnix. Journal of Reproduction and Fertility, 64: 259-266. Available at:https://www.ncbi.nlm.nih.gov/pubmed/7069651.

Das SK, Bhuiyan MMU, Rahman MM, Begum N and Bari FY (2016). Evaluation and effect of native cock semen on diluents and preservation time. International Journal of Veterinary Science, 5(2): 51-57.

De Marchi M, Cassandro M, Targhetta C, Baruchello M and Notter DR (2005). Conservation of poultry genetic resource in the Veneto region of Italy. Animal Genetic 
Research,

37:

63-74.

DOI:https://doi.org/10.1017/S1014233900001978.

Esponda P and Bedford JM (1985). Surface of the rooster spermatozoon changes in passing through the Wolffian duct. Journal of Experimental Zoology, 234: 441-449. DOI:https://doi.org/10.1002/jez.1402340311.

Glover TD (2012). Mating males: An evolutionary perspective on mammalian reproduction. Cambridge., Cambridge University Press, p. 202.

Gunn MR, Champion Z, Casey ME, Teal P and Casey PJ (2008). Testicular and spermatozoan parameters in the pukeko (Porphyrio porphyrio melanotus). Animal Reproduction Science, 109: 330-342. DOI:https://doi.org/10.1016/j.anireprosci.2007.11.002.

Hess RA, Thurston RJ and Biellier HV (1976). Morphology of the epididymal region and ductus deferens of the turkey (Meleagris gallopavo). Journal of Anatomy, 122: 241-252. https://www.ncbi.nlm.nih.gov/pmc/articles/PMC1231898/.

Hicks KD (1992). Ratite reproduction. Proceedings of the Annual Conference of the Association of Avian Veterinarians, 318-325.

Howarth BJr (1983). Fertilizing ability of cock spermatozoa from the testis epididymis and vas deferens following intramagnal insemination. Biological Reproduction, 28: 586-590.

Available at:https://academic.oup.com/biolreprod/articleabstract/28/3/586/2766197.

Jones RC and Lin M (1993). Spermatogenesis in birds. Oxford Reviews of Reproductive Biology, 15: 233-264. Available at:https://www.ncbi.nlm.nih.gov/pubmed/8336978.

Jones RC, Clulow J, Kidd G, Chaturapanich G, Nixon B and Dacheux JL (2003). The avian epididymis: a simple conduit or a sophisticated adaptation. In The Third International Conference on the Epididymis,138-148.

Kumar E and Holt WV (2014). Impacts of endocrine disrupting chemicals on reproduction in wildlife. Advances in Experimental Medicine and Biology, 753: 55-70. DOI:https://doi.org/10.1007/978-1-4939-0820-2_4.

Kuzlu ,M. and Taskin A (2017). The effect of different extenders on the sperm motility and viability of frozen Turkey semen. Indian Journal Animal Researche, 51 (2): 235-241. DOI:https://doi.org/10.18805/ijar. v0iOF.6825.

Łukaszewicz E, Jerysz A, Partyka A and Siudzinska A (2008).Efficacy of evaluation of rooster sperm morphologyusing different staining methods. Research inVeterinary Science. DOI:https://doi.org/10.1016/j. rvsc. 2008.03.010.

Mamuad FV, Venturina EV and Saito H (2004). Collection, processing and handling buffalo semen. Water buffaloes and beef cattle improvement project. A joint JICA assisted project of the Philippine Carabao Center and the Bureau of Animal Industry, Philippines. Pp.1- 60.

Mavi G K, Dubey PP and Cheema RS (2017). Comparison of Sperm Attributes in two Indigenous Layer Breeds and their Relationship with Fertility. Theriogenology Insigh, 7(2): 123-129.

3371.2017.00028.6.
Mavi G K, Dubey PP, Ranjna S C , Dash SK and Bansal BK (2018). Comparative analysis of semen quality parameters and their relationship with fertility in different genetic groups of layer chicken. Indian Journal of Animal Research,DOI: https://doi.org/10.18805/ijar.B-3646.

Mohammadzadeh S, Maksudov GY and Doronin YK (2011). Survival of spermatozoa in the genital tract of mice post-mortem. Doklady Biological Science, 436: 62-64. DOI: https://doi.org/10.1134/S0012496611010078.

Mphaphathi ML, Seshoka MM, Luseba, D, Sutherland B and Nedambale TL (2016). The characterisation and cryopreservation of Venda chicken semen. Asian Pacific Journal of Reproduction, 5(2): 132139.DOI:https://doi.org/10.1016/j.apjr.2016.01.009.

Munro SS (1935). Motility and fertilizing capacities of fowl sperm in the excretory ducts. Proc Soc Experimental Biology and Medecine. 33: 255-257. DOI:https://doi.org/10.3181/00379727-33-8331.

Munro SS (1938). Functional changes in fowl sperm during their passage through the excurrent ducts of the male. Journal of Exprimental Zoology banner, 79: 71-92. DOI:https://doi.org/10.1002/jez.1400790106.

Obidi JA, Onyeanusi BI, Rekwot PI, Ayo JO and Dzenda T (2008). Seasonal variations in seminal characteristics of characteristics of Schikab-rownbreesder cocks. International Journal of Poultry Science, $7:$ 1219-1223. https://pdfs.semanticscholar.org/.../c266b48542a280dad29 e36756.

SalisburyGW, Vandemark NL and Lodge JR (1978). Physiology of Reproduction and Artificial Insemination of Cattle, pp. 138 .

Salting VB, AquinoFP, Ma ElizabethDC, Leoveras, Ma EDC, Ocampo LC, Atabay EP and De Leon AM (2016). Comparison of quality of spermatozoa from the excurrent ducts of Philippine local chicken retrieved by swim-up or mincing methods. Journal of Biological Engineering Research and Review, 3(1): 01-05. Available at:http://www.biologicalengineering.in/Archive.

Sasaki K, Tatsumi T, Tsutsui M, NiinomiT, Imai T, Naito M, Tajima A and Nishi Y (2010). A Method for Cryopreserving Semen from Yakido Roosters using NMethylacetamide as a Cryoprotective Agent.The Journal of Poultry Science, 47:297-301. DOI: https://doi.org/10.2141/jpsa.009111.

SiudzinskiA and Lukaszewicz E (2008). The effet of breed on freezability of semen of fancy fowl. Animal Science Paper and Reports, 4: 331-340. Available at:http://www.ighz.edu.pl/?p0=5\&p1=34\&l=2.

Shanmugam M, Kannaki TR and Vinoth A (2016).Comparison of semen variables, sperm DNA damage and sperm membrane proteins in two male layer breeder lines. Animal Reproduction Science, $172: 131-136$. DOI:https://doi.org/10.1016/j.anireprosci.2016.07.010.

Tabatabaei S, Batavani RA and Talebi AR (2009). Comparison of semen quality in indigenous and Ross broiler breeder roosters. Journal of Animal and Veterinary Advances, 8(1): 90-93. Available at:http://medwelljournals.com/abstract/?doi=javaa.2009.90 93. 
Tarif A, Bhuiyan M, Ferdousy R, Juyens N and Mollah M (2013). Evaluation of semen quality among four chicken lines. IOSR Journal of Agriculture and Veterinary Science, 6(5): 7-13. Available at:http://www.iosrjournals.org/iosrjavs/papers/vol6-issue5/B0650713.

Tingari MD (1971). On the structure of the epididymal region and ductus deferens of the domestic fowl Gallus domesticus. Journal of Anatomy, 109 :423-435. Available at:https://www.ncbi.nlm.nih.gov/pmc/articles/PMC127098 $5 /$.

Tisdell C (2003). Socioeconomic causes of loss of animalgenetic biodiversity: analysis and assessment. EcologicalEconomics, 45: 365-376. DOI:https://doi.org/10.1016/S0921-8009(03)00091-0.

Tunceret PB, Kinet $\mathrm{H}$ and Ozdogan N (2008). Evaluation of some spermatological characteristics in Gerze cocks. Ankara Üniversitesi Veteriner Fakültesi Dergisi, 55 : 99-102. DOI: https://doi.org/10.1501/Vetfak_0000000303.

Villaverde Morcillo S, Esteso MC, Castano C and Santiago Moreno J (2016). Influence of Post-Mortem Sperm Recovery Method and Extender on Unstored and Refrigerated Rooster Sperm Variables: Reproduction in Domestic Animals, 51: 40-46. DOI:https://doi.org/10.1111/rda.12643.

Watson PF (1975). Use of Giemsa stain to detect changes in the acrosome of frozen ram spermatozoa. Veterinary Record, 97: 12-15. DOI: https://doi.org/10.1136/vr.97.1.12.

Woelders H, Zuidberg CA and Hiemstra SJ (2006). AnimalGenetic Resources Conservation in the Netherlands andEurope. Poultry Perspective. Poultry Science, 85 :216222. DOI:https://doi.org/10.1093/ps/85.2.216.

Zanetti E, De Marchi M, Abbadi M and Cassandro M (2011). Variation of genetic diversity over time in local Italian chicken breeds undergoing in situ conservation. Poultry Science, 90: 2195-2201. DOI: https://doi.org/10.3382/ps.2011-01527. 